\title{
Az információs társadalom gondolatának európai szálláscsinálója
}

\author{
In memoriam Jean-Jacques Servan-Schreiber (1924-2006)
}

0

$\mathbf{R}$

$\mathbf{M}$

Á

C

I

Ó

S

$\mathbf{T}$

Á

$\mathbf{R}$

S

A

D

A

$\mathbf{L}$

0

M

A tanulmány Servan-Schreiber legfontosabb könyvét, az 1967-ben megjelent „Az amerikai kihívást” középpontba állítva kalauzolja az olvasót az információs társadalom elmélettörténetének korai időszakába. A hatvanas évek közepét a „poszt-indusztriális” állapot nyugtalan fürkészése, az Egyesült Államok hihetetlen tempójú gazdasági és technológiai fejlődésétől megszédült Európa identitás-és útkeresése jellemzi. Figyelemre méltó, hogy a „riadót” fújó francia újságíró milyen érzékenyen és autentikusan tájékozódik és tájékoztat a korai információs társadalom legfontosabb területein, s emiatt üzenetei számos vonatkozásban mai napig frissek és aktuálisak.

Kulcsszavak: Jean-Jacques Servan-Schreiber, poszt-indusztriális társadalom, menedzsment-technológiák, tudás-ipar, európai versenyképesség

\section{Szerzői információ:}

\section{Z. Karvalics László}

Történész, az információs társadalom kutatója. A Budapesti Mũszaki és Gazdaságtudományi Egyetem Információmenedzsment Tanszékének vezetôje, az 1998-ban alapított ITTK (Információs Társadalom- és Trendkutató Központ) igazgatója 1998-2005 között. 1992 óta az Információtörténelem Múhelykurzus vezetôje. Az információs társadalommal foglalkozó különféle kurzusok tananyagának kidolgozója, számos szakkönyv és tanulmány szerzôje. Legutóbb megjelent könyve: Bevezetés az információtörténelembe (Gondolat, 2004). „Kiváló Oktató” (1999), 2000-tôl Széchenyi-ösztöndíjas. Az információs társadalom témakörében végzett, nemzetközileg elismert kutatásaiért 2004-ben a Magyar Köztársasági Érdemérem Polgári Tagozatának Lovagkeresztje kitüntetést kapta. A Nemzeti Hírközlési és Informatikai Tanács tagja. 2005-ben habilitált az ELTE-n.

E-mail: zkl@itm.bme.hu

Így hivatkozzon erre a cikkre:

Z. Karvalics László. „Az információs társadalom gondolatának európai szálláscsinálója”. Információs Társadalom VII, 1. szám (2007): 124-136.

$=$ https://dx.doi.org/10.22503/inftars.VII.2007.1.13 $\rightleftharpoons$

A folyóiratban közölt müvek

a Creative Commons Nevezd meg! - Ne add el! - Így add tovább! 4.0

Nemzetközi Licenc feltételeinek megfelelöen használhatók. 
Z. Karvalics László

\section{Az információs társadalom gondolatának európai szálláscsinálója}

In memoriam Jean-Jacques Servan-Schreiber (1924-2006)

Az MTI rövid híradását felhasználva szinte valamennyi napilapunk megemlékezett arról, hogy a betegsége miatt már jó ideje visszavonult francia újságíró-politikust, Jean-Jacques Servan-Schreibert 2006. november 7-én, 82 éves korában, a normandiai Fécamp-ban utolérte a halál. ${ }^{1}$

A méltatások a mérnökból lett közéleti személyiségnek, a haladásért, a dekolonializációért harcoló újságírónak szólnak, aki 1953-ban a késóbb legendássá vált $L$ L'Express társalapítója volt, majd a radikális párt színeiben a politika porondjára lépett, és 1974 ben két röpke hétig reformminiszteri tisztet is betöltött. Főmúvét, Az amerikai kihivás címú, 1967-ben megjelent könyvét ${ }^{2}$ „a mai Európai Unió elméleti alapjait” megvetô politikai esszéként emlegetik.

Csakhogy - mintegy mellékesen - ez a könyv „vezeti be” a francia és az európai közgondolkodásba és a szótárba a posztindusztriális társadalom fogalmát („Jegyezzük meg ezt a terminust, sokszor fogjuk még hallani, mert ez definiálja a jövớt”), és ez mutatja be elsóként és részletesen azokat a gazdasági, technológiai és politikai fejleményeket, amelyek az Egyesült Államokat látványos és radikális átalakulás és növekedési pálya - az információs társadalom építése - felé kormányozták az ötvenes évek közepétól, alig egy évtized alatt.

Érdemeit egyáltalán nem csökkenti, hogy nem alakítja, hanem „csak” bemutatja a kortárs - elsôsorban amerikai és francia - diskurzusokat és kutatási eredményeket, ${ }^{3}$

\footnotetext{
${ }^{1}$ Már életében megjelentek róla átfogó monográfiák és méltatások (lásd elsốsorban Rustenholz Alain Treiner, Sandrinc (1993): La Saga Servan-Schreiber: Paris: Scuil, illetve Chapsal, Madeleine (2004): L'homme de ma vie. Paris: Fayard (a szerzó nem más, mint elsố fclesége, akitól 1960-ban elvált, de jó kapcsolatban maradtak mindvégig). Élete alkonyán maga is kétkötetes visszaemlékezéssel segítette a majdani történészck dolgát (Passions [Hachette], 1991, Les Fossoyeurs. Passions. Tome 2. Fixot, 1993).

${ }^{2}$ Le défi Americain. Editions Denocl, 1967. Az amerikai kihívás 600 ezcr eladott példányával Franciaországban azonnal bestscller lett, ćs 15 nyelvre fordították le. Az amerikai kiadást (American Challenge. New York: Atheneum, 1968) Arthur Schlesinger clőszava gazdagította, de nem tartalmazta a hat függcléket. Magyarul a Kossuth Kiadó „illegális”, számozott sorozatában jelent meg 1969-ben 256 oldalon mindennemú szerkesztói segédlet, illetve a tájćkozódást scgítő, az credetiben szereplő szómutató nćlkül, és az eleve pongyola lábjegyzetek negatív hatásait felerôsítố pontatlanságokkal. (Erre lásd elrettentố példaként a 14. számú lábjegyzetet.) Az oldalszám szerinti hivatkozások erre a kiadásra vonatkoznak. Ez a tanulmány a benne lévó pontosítások és kiemelések miatt akár a könyv egyfajta hiányzó „utószava” is lehetne.

${ }^{3}$ 'Tegyük hozzá: nem is akárhogy. Szćles kitekintéssel és forrásismerettel, a társadalomtudományi munkákra, a politikai háttérdokumentumokra és az előrejelzésekre is érzékenyen, sokszor még megjelenés
} 
mert lényeglátása és árnyalt megközelítése révén maga a „kompozíció” és a mögötte álló szemléletmód válik korszerúvé és maradandóvá.

A jelenség, amiból Servan-Schreiber kiindul, az amerikai vállalatok térnyerése Európában. Nem farkast kiált azonban, mint az Amerika-ellenességból mai napig sportot űzô divatgondolkodók (élükön a mind reménytelenebb Paul Virilióval), ${ }^{4}$ hanem megérteni igyekszik a helyzetet: kideríteni, hogy milyen okok állnak a háttérben, és ezek ismeretében megtalálni a lehetséges válaszokat az Atlanti-óceán innensô oldalán. „A veszély nem az amerikai tehetség (az intellektuális és piaci attraktivitás) - mondja -, hanem az európai tehetetlenség, mert az öreg kontinenst gyorsuló ütemú leszakadás fenyegeti, elsôsorban a korszerú menedzsmentmódszerek, az (elektronikai) technológia és a kutatás terén kialakult és egyre növekvő hátránya miatt.

Servan-Schreiber észleli és többször is szükségesnek tartja aláhúzni, hogy nemcsak figyelemre, hanem bizonyos értelemben csodálatra méltó Amerika „példátlan ugrása”, amit a világháború óta hajtott végre. Megdöbbentően újszerú megállapítása, hogy „ma [az USA] gazdaságpolitikájának tulajdonképpeni célja a technikai újítások megvalósítása”. Az „állami tisztviselók, ipari vezetókból, egyetemi közgazdászokból, mérnökökból és tudományos kutatókból” álló „szövetség” tagjai összehangolják és megtervezik a tevékenységüket, kölcsönösen megtermékenyítve egymást (cross-fertilization). (Szerzốnk itt John Kenneth Galbraith terminusát, a technostruktúrát ${ }^{5}$ használja a kialakulófélben lévố társadalmi hálózat megjelölésére, pedig alkalmazhatná a sokkal baljósabban hangzó „katonai-ipari komplexum” elnevezést is, ami Eisenhower elnök 1961. január 17-i búcsúbeszédéból híresült el. $)^{6}$ Servan-Schreiber szimata és tolla nyomán az európai olvasó számára is megelevenedik mindaz, ami az idő tájt megismerhető és elmondható volt az USA páratlan tempójú átalakulásáról.

\section{Tusrajzok az információs társadalom amerikai frontvidékéről}

Az újságíró nem törekszik a teljességre, hanem igyekszik minél kevesebb egyedi jelenség felhasználásával a lehetố legérvényesebb és legátfogóbb képet megrajzolni. Nem realista, részlethú fotográfiával, hanem lendületes, erôs és határozott vonalakból formált kontúrokkal mutatja be tárgyát. És akkor, amikor a tudományos elemzés és megértés csak kullog a hihetetlen tempójú átalakulás mögött, sok esetben többet ér és

\footnotetext{
clốtti állapotukban hozzájutva a legfrissebb kéziratokhoz! Ez persze minden bizonnyal kiváló munkatársának, Michel Albertnek is köszönhetơ, aki az „adatvadászatban” nélkülözhetetlen segítôje volt.

${ }^{4}$ A kérdés francia látószögból megfogalmazott áttekintését lásd Revel, Jean-Francois (2004): AntiAmericanism. Encounter Books.

${ }^{5}$ Galbraith J. K. (1969): Az uij ipari állam. Budapest: KJK (The New Industrial State, 1967). Galbraith technostruktúrája a tốkétốl a szervezett szakértelem irányába való eltolódást jelenti, melynek során szinte kizárólag a tudósok és a mérnökök veszik át a technológiai fejlôdés ellenốrzését, s ennek révén - noha nem tulajdonosi és nem menedzseri a pozíciójuk - újfajta hatalmi-döntési pozícióba kerülnek.

${ }^{6}$ „A kormányzati munkában óvakodnunk kell attól, hogy szándékosan vagy anćlkül indokolatlan befolyásra tegyen szert a »katonai-ipari komplexum«. Eiscnhower elnök búcsúüzenete, 1961. január 17. (Public Papers of the Presidents: Dwight D. Eisenhower, 1960-61, no. 421.) Angolul (teljes egészében) és magyarul (részletekkel) lásd http://www.gcocities.com/szamizdatkiado/cisenhow.htm
} 
többet mond egy effajta, nyugtalanító „tusrajz”, mint egy terjedelmes, de unalmas monográfia. S mivel Servan-Schreiber jó helyekre nyúl, amikor forrásokat keres, ${ }^{7}$ az ô „,vázlataiban” sokoldalúan és gazdagon mutatja meg az arcát a „posztindusztriális” kohóban izzó Amerika - az az ország, amely a könyv írásakor a világ teljes ipari termelésének egyharmadát produkálja, és számos ágazatban domináns szerepet játszik. Ahol tizenöt év alatt sikerült megfordítani a jövedelmi piramist: 1950-ben az amerikai családok 60 százalékának az évi jövedelme 5000 dollár alatt volt, 1965-re pedig a családok 67 százaléka már átlépte ezt a jövedelmi szintet, miközben negyedrészük túljutott a 10 ezer dolláros határon is.

Servan-Schreiber azonban elsốsorban másra figyel. Számára nagyon fontos, hogy az Egyesült Államok az ezer fốre esố egyetemi és fốiskolai hallgatók számában hogyan utasítja maga mögé a világot, hogy az egy foóre esố kutatási és fejlesztési kiadásai majdnem a nyugat-európainak a négyszeresére rúgnak, hogy a technológiai fejlesztési programok terén kimagaslóan az állam a legnagyobb megrendeló, és hogy Amerikában annyira lerövidítették az innovációs ciklust, hogy az „új termékek” piacát majdhogynem egyedül uralják. Kellő hangsúllyal tárgyalja, hogy mindezek nyomán (az automatizáció párjaként) a képzettség és a tudás fontosságának drámai megnövekedése tapasztalható a munkafolyamatokban. Így juthat el végül annak felismeréséhez, hogy az amerikai „titok” egyik kulcsa az oktatásban rejlik. „A ma Amerikája a legbusásabb hasznot minden befektetések legrentábilisabbikából, az állampolgárok szakképzéséból húzza” (53).

Servan-Schreiber legfontosabb forrása ebben a kérdésben a növekedéselszámolás (growth accounting) atyja, Edward F. Denison, ${ }^{8}$ aki az általa kifejlesztett módszerrel könyvelói precizitással „kiszámolta”, hogy az utolsó évtizedek amerikai gazdasági növekedésében mekkora szerep jutott az új „tókeformáknak”, az emberi tókének és a technológiai innovációnak. Megállapította, hogy míg a 20. század elején, a klasszikus „ipari” korszakban a munkáslétszám és a befektetett tốke volt a legfontosabb tényezó, 1929 és 1957 között ezek háttérbe szorultak, és a növekedés két legfontosabb kiváltó oka (a 31 számításba vett tényezô közül) az „általános oktatás” és a „technológiai újitás” (az ismeretek gyarapítása és az oktatásnak a társadalom mind nagyobb részére való kiterjesztése) lett. Harminc év alatt megtízszereződött az oktatásba és a tudományos ku-

\footnotetext{
${ }^{7}$ Ez természetesen egyáltalán nem jelenti azt, hogy Servan-Schreiber alaposan utánajárt volna az általa vizsgált kérdésck kurrens amerikai irodalmának. Láthatóan nem ismeri Peter Druckernek 1967-re már tíz kötctnyirc bővült munkásságát, noha Drucker elsô klasszikus múvei-The Future of Industrial Man, 1942, The New Society, 1950, és különösen a The Landmarks of Tomorrow, Harper and Brothers, 1957, 1958, 1959 - a posztmodern, az innovációs, a szervezeti és az oktatási tematikát is nagyjából olyan mcgközelítésben tárgyalják, mint Az amerikai kihtoás. Pedig francia fordítás is rendelkezćsre állt, még 1958-ból (Drucker, Peter: La pratique de la direction des entreprises. Editions d'Organisation). Druckernek a „tudásmunkás” (knowledge worker) kategóriát bevezetớ múve (The age of discontinuity) csak 1968-ban jelent meg, s ha Servan-Schreibernek van még egy éve, bizonyosan nagyban támaszkodik olyan szerzókre is, mint pl. Harold L. Wilenski (Organizational intelligence. New York: Basic Books, 1967).

${ }^{8}$ Sevan-Schreiber Denison „1965-ben írt értekezésére” hivatkozik, ez minden bizonnyal két évvel késốbb megjelent nagy munkája (Denison, E. F. (1967): Why Growth Rates Differ: Postwar Experience in Nine Western Countries. Washington: The Brookings Institutions). A módszer azonban korábbi, és az igazi mérföldkó egy nagy összchasonlító vizsgálat, az évtized elejéról: Denison, E. F. (1962), The Sources of Economic Growth in the United States and the Alternatives Before Us. CED Supplementary Paper, No. 13, New York: Committee for Economic Development.
} 
tatásba befektetett összeg - és ez a nyomás tovább erôsödik (ennek alátámasztásául Servan-Schreiber egy másik forrást ${ }^{9}$ idéz), mert az urbanizáció fokozódásával együtt járó átlagjövedelem-emelkedés még nagyobb oktatási keresletet támaszt, és a tájékoztatás forradalmával jár majd együtt.

A „titok” másik nyitja a számítógép, amelynek Servan-Schreiber két önálló fejezetet is szentel. A leglényegesebb mozzanatnak - helyesen - a számítógépek alkalmazását tartja a termelésben, ${ }^{10}$ a kormányzatban ${ }^{11}$ és a kutatásban. (A könyv írásakor az amerikai értéktốzsdén például már telefonos árfolyam-információkra kiépített, valós idejü, időosztásos rendszer ${ }^{12}$ múködött). „Az elektronikus számítógépek segítségével, amelyek megsokszorozzák a megismerés és a tervezés lehetőségeit, állandó kapcsolat van a laboratóriumi eredmények, a termelés problémái és a marketing perspektívái [...] között." ${ }^{13}$ És természetesen nemcsak a masinákra, hanem az általuk szállított és feldolgozott információkra is érdemes figyelni: a hatvanas évek közepén az Egyesült Államokban évi 100 ezer múszaki és tudományos jelentés születik, 900 ezer szakcikk lát napvilágot, és 7 ezer könyv jelenik meg.

\section{Az amerikai információ- és tudás-ipar korai európai expanziójának anatómiája}

Servan-Schreiber semmi furcsát vagy kivetnivalót nem talál abban, hogy a már eleve nagy „belsố” piacon felnốtt, korszerú technikát, háttértudást és menedzsmentmódszereket alkalmazó amerikai nagyvállalatok - versenyelő́nyük birtokában - megkezdték az európai piac meghódítását is. Szinte egyenes az arányosság: „minél magasabb valamely iparág múszaki színvonala, annál nagyobb az amerikai részesedés". ${ }^{14}$

${ }^{9}$ A General Learning Corporation (GLC) 1966 januárjában alakult meg a General Electric és a Time közös vállalataként, az amcrikai oktatásügy crôs emberc, Francis Keppcl közvetlen támogatásával. Mindkét cég érdekelt volt abban, hogy a jövő oktatási piacával kapcsolatos friss credmények birtokában tervezzen, s ez találkozott a messzire tekintó Keppel clvárásaival, aki az ipar szereplőinck aktívabb szerepvállalását szorgalmazta az amerikai iskolákban, és The Necessary Revolution (1966) címú könyvében az oktatás „kapitalizációját” és „technologizálását” sürgette. Miután 1966-ban visszavonult, Keppel lett 8 évre az új cég elnök-vezérigazgatója, a köztes hónapokban pedig Richard Shetler, a General Electric rakétavédelmi kutatásokban és menedzsmentben érintett kiváló szakembere vezette az új kutatóintézetet, amelynck az 1980-ig futó idôszakra vonatkozó clsố jelentését dolgozta fel Servan-Schreiber.

${ }^{10}$ 1965-ben 40 ezer gép segítette a termelés-szervezés feladatát, köztük az UNIMATE, az clső ipari robot (1961) révén már a termelésbe is behatoló elektromechanikus „hibridek”.

${ }^{11}$ A szövetségi kormány által a hatvanas évek közepén használt 2000 számítógép óriási mennyisćg, különösen, ha figyelembe vesszük, hogy az ötvenes évek közepén ennek összesen a fele volt csak rendszerbe állítva. Elindultak már a korai ágazati „nagyszámítógépes” rendszerck is, a NASA, az országos orvosi könyvtár, a honvédelmi minisztérium, a kereskedelmi minisztérium és más szervek önálló kezelésében.

${ }^{12}$ A magyar ,zugfordító” - mint számos más esetben is - a terminológia ismerete nélkül ültette át a francia/amcrikai terminusokat: czt a két kifcjezést például „reális idốnek” és „megosztott idốnck” fordította.

${ }^{13} 51$. o., a Közös Piacnak a tudományos és technikai tervezésért felelốs tisztvisclóje, Pierre Cognard úti jegyzetci nyomán.

${ }^{14}$ Servan-Schreiber a magyar verzió szerint a Columbia Egyetem „fiatal kutatója”, Donald Koesing „kiadatlan tanulmányából” idézi ezt az állítást. Ember legyen a talpán, aki ebból kiindulva kívánna a hivatkozott szerzó nyomába credni. Servan-Schrciber forrása ugyanis valójában Donald B. Kecsing (1964-tól a Co- 
A korszerú elektronikai termékek gyártása Európában - minél újabb eljárásról van szó, annál inkább - amerikai ellenőrzés alatt áll, az alábbi részesedési arányok mellett:

- $15 \%$ a szórakoztató elektronikai termékek,

- $50 \%$ a félvezetók,

- $80 \%$ a számítógépek, és

- $95 \%$ az integrált áramkörök gyártása terén. ${ }^{15}$

Nem véletlen tehát, hogy Európa polgárai a hatvanas évek közepén egészen furcsa körülmények között zajló számítógép-háború ${ }^{16}$ szemtanúi lehettek.

Noha a számítógépek történetét az elektroncsöves korszakban a német Zuse gépe(i) és a brit Enigma révén Európában kezdték írni, a tranzisztoros korszakban már az USA került az innovációs verseny élére, az integrált áramkörökre épüló harmadik nemzedék pedig már a tengerentúliak elsöprố dominanciáját hozta. És nemcsak az „asztali” gépekben, hanem a rakétákban, atom-tengeralattjárókban és repülőgépekben is, kiterjesztve az elektronikai fölényt a gépiparra is. A sikert persze nem adták ingyen. Az IBM egymaga akkora összeget (négy év alatt 5 milliárd dollárt) fektetett híres „360-as szériájának” kifejlesztésére, mint amennyit a kormányzat invesztált ugyanakkor az ûrkutatásba. Ezt a lépést például a talán egyedül lehetséges európai versenytárs, a Philips - utólagos bevallása szerint elhibázott helyzetelemzésból fakadóan - nem merte megtenni, így aztán teljesen ki is maradt az innováció fớsodrából, és meg kellett elégednie a hagyományos termékek részpiacán elfoglalt helyével. Servan-Schreiber rámutatott, hogy az elszigetelt német, francia vagy brit erôfeszítések (elsősorban a piac korlátozott mérete és az erôforrás-koncentráció hiánya miatt) eleve kudarcra vannak ítélve, Európa természetes válasza csakis a koncentráció, a csúcstechnikai fejlesztés fokozódó integrációja lehet. ${ }^{17}$

lumbia egyetem közgazdászprofesszora) monográfiájának kézirata. Ennck a 23. oldalán olvasható az a hipotézis, hogy a mûszaki színvonal mércéje a tudományos kutatóknak és mérnököknck az alkalmazottak összlétszámához mért aránya. Keesingnek ez a munkája nem jelent meg könyv formában, de a szerző a Journal of Political Economy 1967. februári számában „The Impact of Rescarch and Development on United States Trade" címmel megjelent tanulmányában közzétette eredményeit (Vol. 67, 38-48).

${ }^{15}$ Servan-Schreiber itt Bertin, Gilles (1963): L'investissement des firmes étrangéres en France címú könyvére támaszkodik

${ }^{16}$ 11. fejezet, 103-110. o. Ebben a fejezetben néhol ki-kiütközik Servan-Schreiber „outsider” mivolta, különösen a szoftver fogalmának körülírásakor - arra azonban nagyon is helyesen tapint rá, hogy az anyagköltségen kívül szinte semmi más beruházást nem igénylô, csupán a megfelelốen felkészített humán tốkére támaszkodó szoftverágazat európai kitörési pont lehet. Arról pedig persze nem ố tehet, hogy mindebból (a $S A P$ „nagy menetclését” leszámítva) negyven év alatt sem lett curópai üzleti siker.

${ }^{17}$ Korábbi szerepéból kicsit kilépve Servan-Schreiber itt nagyon is konkrét javaslatot tesz: Anglia mint középpont körül véli kićpítendőnck a nyugat-curópai koncentrációt. Elsố látásra furcsának túnhet a felvetés, de ha belegondolunk, hogy a britck „maradtak” lcgközclebb a számítógép-fcjlesztési alapkutatásokhoz, sốt a hatvanas ćvek elcjén a majdani internet múködésćt biztosító eljárások kidolgozásában is párhuzamosan haladtak az amerikaiakkal, nem is olyan földtól clrugaszkodott az ötlet - más kérdés, hogy a „nagynemzcti” öntudatok akkor vajmi kevés csélyt adtak cffajta szövetkezésre. Amire viszont akkor látható piaci dimenziók hiányában sem ố, sem mások, de még az amerikaiak sem gondoltak: a mobiltelefónia lehetett volna valódi kitörési pont. Akkorra már jelentốs volt az curópai clôny, hiszen az Erricsson cég a svéd távközlési hatóság számára már 1956-ban kiépítette elsố mưkööő automata rendszcrét, ami egyszerúen csak a Mobil Telefon A (MT'A) nevet kapta, és valódi mobil szolgáltatást nyújtott Stockholm és Göteborg néhány száz magas jövedelmú orvosa és ügyvédje számára. 
Külön érdeme, hogy az elsók között figyel fel arra, hogy a nagy amerikai tanácsadó irodák (a Booz, Allen \& Hamilton, az Arthur Little és a McKinsey) a hatvanas évek eleje óta minden évben megkétszerezik európai létszámukat - az önmagában is exportképes amerikai piaci, marketing- és menedzsmenttudás látható jeleként. Ennek értékelése, mint cseppben a tenger, jól tükrözi Servan-Schreiber álláspontját az amerikai térnyerésról: Az amerikai tudás megjelenése és „szétterülése” hasznos az európai ipar számára, mert korszerú és versenyképes „mintázatok” elterjedését eredményezi, az viszont természetesen messzemenôen negatív hatású, hogy a hatvanas évek első felében 5 év alatt több mint 10 ezer európai tudós vándorolt ki az USA-ba. ${ }^{18}$ Ám ugyanez igaz (volt és lett) a „nagy képre” is: a tegnap és a jelen amerikai innovációs fölénye a jelen és a jövố termelési, szervezési, irányítási struktúráinak, a mindennapi életnek és a kultúrának az egyetemleges átalakítását eredményezi. A verseny megmarad ugyan, de közben a világ átmegy egy fejlettebb, izgalmasabb, talán egy kicsit emberarcúbb, de a régitól bizonyosan alapvetôen különbözố posztindusztriális állapotba. ${ }^{19}$

\section{A posztindusztrialitás mint jövőkép}

Amikor a posztindusztriális társadalom következő évtizedeinek kérdése kerül terítékre, Servan-Schreiber legfontosabb kiindulópontja két friss amerikai szakanyag: a Hudson Intézet akkor még megjelenés elốtt álló, de aztán nagy figyelmet kiváltó és világszerte ünnepelt előrejelzése, A 2000. ér, ${ }^{20}$ valamint a számítógép-központú jövóbe tekintő Knox-jelentés.

A Hudson Intézet jelentésében a nemzetközi intézmények átalakulásától az atomfenyegetésig sok téma elókerül, Servan-Schreibert mégis az új, posztindusztriális minôségról a jelentés terjedelmes IV. fejezetében megrajzolt kép érdekli a legjobban.

${ }^{18}$ Az agyelszívásról szóló részben a szerzố forrása Dimitri N. Chorafas, akinek a megjelenés elốtt álló új könyvét - jó szokása szerint - már kéziratban is módjában állt elolvasni. A The Knowledge Revolution: An Analysis of the International Brain Market címú munka (1968, George Allen \& Unwin, McGraw-Hill, 1970) nemzetközi összchasonlító vizsgálatok alapján tekinti át az Európa és Amerika közötti „agyáramlás” mérlegét, ServanSchreiberćhez kisértetiesen hasonló küldetésnyilatkozattal: „This book has been written to discuss Europe's economic and cultural future ... It is examining the role of industry, government and universities in meeting the challenge of the 1970s and thereafter:" S mivel mindehhez Chorafasnak - már akkoriban is a tudományos menedzsmenttel foglalkozó irodalom ismert szereplôjeként, nyole szakkönyvvel a háta mögött - az „agy-elvándorlás” teljes problémakörnyezetét be kellett mutatnia, mûve sok esetben kínál Servan-Schreibernek „importálható” szempontokat az Amerikai kilivós más fontos részeihez is. Ilyenek a tudásiparról szóló (7. The Knowledge Industry), valamint az oktatás és a szakemberképzés összekapcsolásával foglalkozó (8. The Educational „,Residual” and the Brain Factories) vagy éppen a vállalati szervezetet (6. New Challenges for Management), illetve az egyetemek és az ipar kapcsolatát (9.) s végül az európai közösség integrációjának szükségességét (11. és 12.) tárgyaló fejezetek. Halkan jegyezzük meg, hogy Servan-Schreiber az agyelszívással foglalkozó passzusokon kívül sehol másutt nem hivatkozik Chorafasra.

${ }^{19} \mathrm{Az}$ amerikaiak pedig megérdemlik a nagy üzleti sikert - sugallja Servan-Schreiber -, mert nekik köszönhetjük, hogy czek a változások megindultak, és világméretûvé váltak: kinyílt az ablak egy egészen újszerú jövó irányába.

${ }^{20}$ Kahn, Herman - Wiener, Anthony (1967): The Year 2000. A Framework for Speculation of the Next Twenty-Three Years. Hudson Institute, 460. 
Az elốrejelzés a formálódóban lévố új társadalomtípus jellemzóit tizenöt tételben sorolja fel. Ezek nagy részét Servan-Schreiber átveszi, néhányat közülük azonban félreolvas, másokat pedig kihagy. Az iparral, a társadalmi állapottal és az innovációval kapcsolatos „pontokat” tartja fontosnak, ezeket szinte „tükörfordításban” adja vissza, miközben az értékek átalakuló világára vonatkozó állításokat majdnem teljes mértékben mellôzi. ${ }^{21}$

Milyen lesz a posztindusztriális (és tömegfogyasztás utáni) társadalom?

1. Az egy főre jutó nemzeti jövedelem ötvenszeresére nő a preindusztriális korszakhoz viszonyítva. (I)

2. A gazdasági tevékenység súlypontja a termékorientált elsődleges és másodlagos szektor felól a szolgáltatásorientált harmadik és negyedik szektorra tolódik át. (II)

3. Az innováció elsốdleges forrásai többé nem a vállalatok. (III)

4. A közbeszédet és a politikát egyre kevésbé a piac, s mindinkább a közösen kiformált és elfogadott elképzelések alakítják (consentives vs. marketives).

5. A jövedelmek és az életminôség (income and welfare) terén csökken az egyenlőtlenség. (VIII)

6. A termelékenység már nem elsődleges cél.

7. A piacok a közszférához és a szociális alapokhoz képest egyre kisebb szerepet játszanak. (IV)

8. Széles körben elterjed a számítógépes irányítás (akkori kifejezéssel: cybernation). (V) [Ezt a trendet Servan-Schreiber - helytelenül - az ipari termelés számítógépes irányítására szúkíti le.]

9. A világ „összezsugorodik” (small world). (VII) [Schreibernél: „A tér és az idő nem lesz az érintkezés akadálya."]

10. A népesség növekedésének tipikus „duplázódási ideje” három és harminc év között lesz.

11. „Tanuló társadalom” (learning society) alakul ki.

12. Az oktatási intézmények és technikák villámgyorsan fejlődnek. (VI) [Schreibernél: „A haladás fố tényezójét a nevelési rendszerek és a szolgálatukba állított technológiai újítások fogják jelenteni."]

13. A munka- és elốmenetel-központú, célorientált értékek erodálódnak (elsősorban a középosztálynál).

14. Devalválódnak a „nemzeti érdek” fogalmához kötődố értékek.

15. Központi fontosságúvá válik a környezetét tudatosan érzékelô, szekularizált, humanista, önmagát kényeztető́ ember eszménye.

A nemzetállamoknak az egy fớre jutó bruttó nemzeti össztermék (GNP) alapján kirajzolódó majdani sorrendjét tekintve a Hudson-jelentés szerzói egyszerúen a 4 ezer dolláros szintnél húzzák meg a határt: amelyik ország e fölé a szint fölé kerül, az „,belép” a posztindusztriális társadalmak közé. A prognózis szerint 2000-re mindössze 5 ország ugorja át a küszöböt: az Egyesült Államok, Japán, Kanada, Svédország és Svájc (az utóbbit Servan-Schreiber kihagyja a felsorolásból). Kína, India, Latin-Amerika és Afrika még az ipari fázisig sem jut el.

${ }^{21}$ A felsorolás a Hudson-jelentésben foglalt tételeket az eredeti (arab számozással jelölt) sorrendben tünteti fel (The Year 2000, 25 és 186). A Schreiber által választott sorrendet a zárójelben megadott római számok jelzik (28-29). 
Nyugat-Európa, Ausztrália és Új-Zéland, Izrael, valamint Kelet-Európa országai (a Szovjetunió, Lengyelország, Csehszlovákia, Kelet-Németország) alkotják a „fejlett ipari társadalmak" kategóriáját. Ezek a társadalmak majd egy következố lépcsóben válnak posztindusztriálissá, mögöttük pedig Délkelet-Ázsia és Dél-Amerika fejlettebb államai készülődnek a harmadik lépcsóben.

Ha a „posztindusztriális társadalmaknak” ezt a rangsorát összevetjük az ,információs társadalom" fejlettségét tükröző mai indexekkel és readiness mutatókkal, azt találjuk, hogy ez a sorrend - Kelet-Európa „túlértékelésétól” és Délkelet-Ázsia „alulértékelésétốl" eltekintve - nagyjából megegyezik a mai sokváltozós, komplex indikátoros országrangsorokkal, avval a fontos különbséggel, hogy az „élcsoport” nem 4-5, hanem 25-30 tagú lett.

Ez a rangsor a politikai döntéshozóknak szóló üzenetként az Európát felrázni igyekvő Servan-Schreibernél sokkal hangsúlyosabb, mint magában a Hudson-jelentésben. ${ }^{22} \mathrm{Ott}$ - javarészt az elốszót is jegyzố Daniel Bell nyomán - inkább a munkaidő és az elidegenedés radikális csökkenését, a munkavállalók megnövekedő szabadságfokát, általában a munkának a humanizálódás irányában alakuló világát emelik ki (épp azt a területet, ahol mai szemmel a legnagyobbat tévednek). ${ }^{23}$ Ezt, mint vonzó jövóképet természetesen Servan-Schreibernek is meg kell mutatnia, hiszen szüksége van olyan üzenetre is, ami „mindenkihez” szól.

Ehhez kapóra jön az úgynevezett Knox-jelentés, ${ }^{24}$ amely a számítógépes jövôt már-már történetfilozófiai mélységgel, de népszerûsíthetố módon tárgyalja. ServanSchreiber kivonatát tovább kivonatolva azért mutatom be e dokumentum legfontosabb állításait, hogy egyfajta „tematikai térképet” kapjunk a hatvanas évek közepén „eljövendóként" sejtett posztindusztriális, számítógépre alapozott és a tudás világát felértékelő társadalom legfontosabb attributumairól.

- A nyolcvanas években kisméretú, nagy teljesítményú és olcsó számítógépek állnak majd mindenki rendelkezésére, a gépkocsi kezelésének egyszerúségével, otthon és irodában is használható kezelőfelülettel.

- A számítógép interaktív partnerré válik, döntést támogat, valós idốben válaszol (akár szóban is), akár egyszerre sok száz felhasználónak.

-1980-ra a hagyományos közmúvekre (a villany-, víz- és gázszolgáltatásra) emlékeztető, országos méretû́ elektronikus információs hálózatok épülnek ki.

${ }^{22} \mathrm{Az}$ „információs társadalom” fejlettségénck szisztematikus mérése alapján kialakított országrangsorok pionírja, az IDC 1994 óta teszi közzé saját indexeit, s ezekhez csatlakoztak az elmúlt években a népszerú e-readiness sorrendek, valamint az információs ágazatok vagy a tudásszektor fejlettségén alapuló rangsorok. A listák azóta a stratégiai tervezéssel és az információs társadalommal kapcsolatos közbeszédben hangoztatott ćrvek jellegzetes forrásaivá lettek: ennek a „pozíciónak” az ôsképét lelhetjük fel Servan-Schreibernél 30 évvel korábbról.

${ }^{23}$ Például 218 szabadnappal számolnak egy évben - ennek jó, ha a fele igaz például a mai Amerikában. A fekcte népessćg hatalmas relatív számbeli gyarapodását és „középosztályosodását” jósolják - ehhez képest az afroamerikaiak részaránya az USA lakosságában jelentốsen csökkent (igaz, hogy elsốsorban a felerôsödött latin-amerikai és ázsiai bevándorlás következtében).

${ }^{24}$ Servan-Schreiber a Fehér Háznak az új információs és kommunikációs fejlốdési lehetốségckre szakosodott „külön tanácsadójaként” említi Knoxot, aki feltchetốen azonos a hatvanas évek közepén az Office of Science and Technology kötelékében „technical assistant” minőségben múködött William T. Knoxszal. 
- Ezek a „terminálok” és a mögöttük álló óriási kapacitású gépek ${ }^{32}$ együttesen könnyúszerrel kezelik és tárolják az egész világ „teljes írásbeli dokumentációját”, a nyomtatott papír világa lehanyatlik.

- A számítógépek „bevonulnak” az oktatásba, és még a legszegényebb iskolákban is alapeszközzé válnak.

- A múholdak olcsóbbá teszik a távközlést, és forradalmasítják a képek átvitelét is.

- A technikailag fejlett országok és a lemaradók között növekszik a szakadék.

A fejlesztési irányok jól látszanak tehát, a döntéshozóknak csak komolyan kellene venniük óket. Servan-Schreiber bízik benne, hogy ez a forgatókönyv „némi szerencsével talán a cselekvés könyve lehet” (212).

Nos, természetesen nem lett az. Az ezredforduló környékén a kibővült Európai Unió (többek között) az ún. „lisszaboni programmal” ugyan látszólag csatába szállt „a tudás Európájáért", ám a megcélzott felzárkózás helyett mind a kutatás és fejlesztés, mind az innováció, mind a tudásipar területén éppen hogy romlottak ez európai pozíciók. Servan-Schreiber látlelete ezért gyakorlatilag ugyanannyira aktuális, mint volt negyven éve. Látszatra közhellyé kopott alaptézisei („Az emberi ész kimúvelése, fejlesztése, hasznosítása az egyetlen erôforrás [...] Az ész valamennyi eszközének állandó felhasználása és tökéletesítése" 211) is egészen addig érvényben maradnak, amíg mások szájában ezek a szavak a valódi változtatási szándék hiányát leplezik, és nem az ezekból fakadó, nagyon is kézenfekvố stratégiai lépések szervezik a politikai és gazdasági cselekvést. Servan-Schreiber látja ezt is, és afféle szellemi végrendeletként megjegyzi, hogy a posztindusztriális „újjászületés” programjának megvalósításához különleges fajtájú vezetốkre (politikai, gazdasági és szakszervezeti döntéshozókra) is szükség van. Óket nem ott találjuk, ahol a hazafias szónoklatok vagy a politikai összecsapások kürtszava harsog: tevékenységüiket az elemzés ötletessége, a gondolkodás szigorú következetessége és a tennivalók pontos meghatározása fogja jellemezni. ${ }^{26}$

\footnotetext{
${ }^{25}$ Meg kell jegyeznünk, hogy a „nagygép” itt - a kor általános felfogásának megfelelóen - „központi” számítógépet jelent: noha a számítástechnika az elosztott rendszerek irányába fejlôdött, a hatvanas évek végéig élt (a tudományos fantasztikus irodalom és film világa által is felerôsített módon) a minden fontos funkciót ellátó és szabályozó „egyetlen” szuperszámítógép mítosza.

${ }^{26} 2006$ augusztusában - afféle búcsúüzenetként a hazai információs társadalmi közéletnek - „A pálya újravonalazása" címmel arról írtam az egyik országos napilapban, hogy a választóvonalat nem a jelenlegi pártpolitikai megosztottság térképén kell keresni, mert az „,ipari korszak” és az ,információs korszak” politikusait a szakképzettség, a jövőérzékenység és a politikai felelôsség ethosza különbözteti meg egymástól. Ha azt a cikket ma kellene megfogalmazni, akkor bizonyos, hogy Servan-Schreibernek ezzel a gondolatával kezdeném (vagy végezném). Hazája politikusairól beszélve ô is erôsebben fogalmaz: a francia közigazgatást a bizalmatlanság, a gyámkodás, a kezdeményezésre való képtclenség és a túlhajtott ellenôrzés jellemzi, hiányzik a „tervszerúség” és „a koponyákkal való gazdálkodás” igénye (195-199). Hiányzik „a politikai akarat, amcly egységes terv szerint irányíthatná az ország intellektuális erőforrásainak fejlesztését". Az clit érzéketlen az intellektuális „véráramban” kulcsszerepet játszó gyatra telefonellátottsági helyzet megváltoztatása iránt, hagyja „lepusztulni” a posta- és távírógépezetet, amely nem is olyan régen még óramúpontossággal dolgozott. Az érdekes az, hogy Franciaországban éppen ez utóbbi területeken hoz jelentôs változásokat a következő évtized: a telefonellátottság kiemelt, országos akciósorozat eredményeként megjavul, a Minitel program révén pedig - sok évvel megelőzve az egész világot - innovatív és közösségi jellegú hálózati kultúra épül ki (más kérdés, hogy cbból Franciaország nem tud nemzetközi versenyelő́nyt kovácsolni).
} 


\section{Utójáték}

Servan-Schreiber $A z$ amerikai kihivás befejezésében így fogalmaz: „A civilizációk összecsapása ma már az egész földgolyóra kiterjedô érvényességgel a technológia, a tudomány, a vezetés harcmezején zajlik le” (209). Nem véletlen tehát, hogy „A japán kísérlet" címú, néhány oldalas fejezet megírása után, amelyet a könyv függelékében tett közzé, figyelme fokozatosan Japán felé fordul. A távol-keleti szigetország már Az amerikai kihívás hasábjain is fel-felbukkan mint a koncentrált iparfejlesztés és az amerikaiakkal versenyezni képes innovációs stratégia szempontjából követendô példa. Japán diadalmas felemelkedése, ami a számítógépesítés és a tudatos gazdasági és politikai vezetés révén már a hetvenes évek közepétól egyfajta „alternatív információs társadalom” felé mutat, látványos bizonyítéka annak, hogy a „kihívás” nemcsak Amerika felól érkezik, hanem már globálissá nốtt. Ennek a „könyvbe öntése” Servan-Schreiber következố bestsellere, az 1980-ban megjelent Le Défi mondial (A világméretú kihívás). Ebben elsősorban Japánra koncentrál, de immár nemcsak Európára, hanem a „harmadik világra” is vonatkoztatva a „kihívást” és a válaszkeresést. A számítógépekre vonatkozó elemzés pikantériáját az adja, hogy a Knox-jelentésból 1967-ben átemelt ,jövôképnek” gyakorlatilag egyetlen eleme sem valósult meg 1980-ra: nem történt meg sem az olcsó személyi számítógépek elterjedése, sem a közmúszerú óriáshálózat kialakulása, késett a digitális dokumentáció paradigmaváltása, és továbbra is váratott magára az oktatás „átitatása" informatikával. Ám ezek, mint tudjuk, a következô két évtizedben lépésrốl lépésre mégiscsak valósággá lettek, a mikroszámítógépek detonációjától az internetig. Ahhoz azonban, hogy a technológiai forradalomból társadalmi-gazdasági változás legyen, különösen a „harmadik világ” esetében (amelynek Servan-Schreiber egyenesen a megmentôjét látja a számítógépben) sokkal több idôre lesz még szükség, így ez a várakozása könnyen túnik elhamarkodott próféciának. A kritikusok keményebben is fogalmaznak: az automatizáció és a robotizáció új hullámával, a számítógépes forradalommal és az ipar alapját jelentő „új tudáskészletek” termelésével kapcsolatos téziseit „egy technokrata bizarr reményeiként" ${ }^{27}$ mintegy megmosolyogva kezelik. ${ }^{28}$ A témában tett utolsó számottevố megszólalása, a „kihívássorozat” harmadik darabjaként megjelent esszéje pedig még ennél is rosszabb sorsra jut: a The knowledge revolution: New American

\footnotetext{
${ }^{27}$ Lásd elsốsorban Smith, Paul (1989): Visiting the Banana Republic. Social Text, No. 21, in: Universal Abandon? The Politics of Postmodernism, 128-148.

${ }^{28}$ A kritikusok természetesen túloznak, és Servan-Schreiberen verik el a port más, általuk nem kedvelt szerzók helyett. Ráadásul Servan-Schreiber nem „egyoptikás gondolkodó”. Miközben teljes mértékben - és helyesen - meg van gyổzốdve arról, hogy korszakalkotó változások következnek, jól látja a növekvố technológiai szakadékot, és tisztában van avval, hogy az átalakulás számos mozzanata „traumatikus” lesz az érintettek számára. Egyetértóleg használja ćs idézi Simone de Beauvoir gondolatait a fogyasztás korlátozásáról és a morális megújulás szükségessćgéró1.

${ }^{29}$ Miután az információtechnológia promóciója ćrdckében létrehívott párizsi központot pénzhiány miatt bezárják, a csalódott Servan-Schreiber 1984-ben Pittsburghbe költözik, a Carnegie Mellon Egyetemen tanuló fiához, és az egyetem nemzetközi kapcsolataićrt felelős igazgatóként kezd dolgozni. (Mégis clég furcsán hangzik a szájából, amikor egyes gondolatmeneteiben a japánok az „ốk”, az amerikaiak pedig a „mi”.) Barbara Crecine-nel közösen jegyzett könyve már angolul jelenik meg először, a Carnegic Mellon Press gondozásában. Tartalma részben laudáció az egyetemnek és a városnak, valószínúleg ennck köszönhetốen vált cgyáltalán megjelentethetôvé. A könyvnyi terjedelmet is csak kreatív tördelésének köszönheti.
} 
challenge címú, 111 oldalas munkáját ${ }^{29}$ szinte teljes közöny fogadja 1986-ban. Megérdemelten. Szétesố, különbözố stílusrétegeket keverô, az alkotóerố hanyatlását jelző könyvecske. ${ }^{30}$ Hiába jellemzik alapvetốen helyes, elfogadható, sokszor aforisztikus tömörséggel megformált, tézisszerú állítások, ${ }^{31}$ ha az élet és a szakirodalom akkorra már jócskán „túlhaladt” Servan-Schreiberen. A nyolcvanas évek közepén ugyanezekról a kérdésekról már kemény változókkal, empirikus vizsgálatokkal, komoly tudományos apparátussal segített kutatások és monográfiák nyomán alakulnak a narratívák. A váteszek kora lejárt.

\section{Mérleg}

A 2007. évi tavaszi EU-csúcsra készülve érdekes tanulmányt tett közzé egy kutatócsoport 2006 októberében. ${ }^{32}$ Az Európai Uniót az Egyesült Államokkal összehasonlítva azt találták, hogy a foglalkoztatottak aránya a tudásalapú iparágakban mindkét kontinensen egyaránt 38 százalékos. ${ }^{33}$ A növekedési ráták is szinte azonosak az utolsó tíz évben (1995-2005). Csakhogy a kutatás és fejlesztés terén az amerikai befektetéseknek a GNP-hez viszonyított aránya (és volumene) nemcsak továbbra is meghaladja az Unió hasonló mutatóit (2,7\% USA, 1,9\% EU), de a tartósan lassúbb növekedés miatt a belsố arányok is fokozatosan eltolódnak: 1995-ben az EU bruttó értékben még az amerikai összeg 77 százalékát ruházta be ezeken a területeken, s ez az arány tíz év alatt 72 százalékra esett vissza. A legnagyobb különbség azonban az, hogy míg a tudásszektorban foglalkoztatottak létszámának növekedése Európában termelékenységcsökkenéssel járt, addig az USA-ban fokozta a termelékenységet. S hogy vajon miból fakad ez a különbség? A London School of Economics tanulmánya szerint az amerikai elôny egyik legfontosabb tényezốje még mindig az USA szervezeti és menedzsmentkultúrájának a fölénye, ${ }^{34}$ de korábbi

${ }^{30}$ Ha valami miatt a kérdéskör historiográfiájában mégis helyet kaphat, az a kétes értékú „legnagyobb tévedés Afrikával kapcsolatban" rovat lchetne. Egy konferencián való élménydús részvétele nyomán a tudás világtérképén nagy szerepet jósol a fekete kontinensnck („,The conclusive proof of the creative power of Knowledge will come from Africa. We already have enough evidence to anticipate it" [99]).

${ }^{31}$ Néhány izgalmasabb kulcsszót emeljünk ki: eróltetett felsốoktatás-fejlesztés teljesen számítógépesített kampuszokkal. Általános számítógépes írástudás (computer literacy). A termelésszervezésben clért japán clő́nyt a számítástudományban megszerzett fölény megtartásával ellensúlyozó Amerika - különös tekintettel a szoftverkapacitásokra. Az oktatás egyes számú nemzeti prioritássá tétele.

${ }^{32}$ Brinkley, Ian - Lce, Ncil (2006): The Knowledge Economy in Europe. A report prepared for the $2007 \mathrm{EU}$ Spring Council. The Work Foundation.

${ }^{33}$ A skandináv országok, Hollandia és Nagy-Britannia esetében ez a szám jóval magasabb, mint az USA-ban, az curópai átlagot a „gyengébben teljesítô” tagországok „, húzzák le”. Persze ha Virginiát, Kaliforniát vagy Massachusettset „emelnénk ki” az amerikai átlagból, akkor velük már nem tudna versenyezni Európa élvonala sem.

${ }^{34}$ Bloom, Sadun - Van Recnen (2004): „IT ain't what you do it's the way that you do it - testing explanations of productivity growth using US affiliates”. Centre for Economic Performance, LSE, September, 2005.

${ }^{35}$ Patel, P. - Pavitt, K. (1987): „Is Western Europe Losing the Technological Race?” In Frecman, C. (ed.): Output Measurement in Science and Technology. Amsterdam: North-Holland, 59-85. Nclson, R. (1989): „U.S. Technological Leadership. Where Did It Come From and Where Did It Go?" Research Policy, 19, 2: 117-132. Pianta, M. (1988): New Technologies across the Atlantic: U.S. Leadership or European Autonomy? Hemel Hempstead: Harvester-Wheatsheaf. 
elemzések ${ }^{35}$ sem tudnak jelentôs mértékben mást mondani erról, mint negyedszázaddal elốttük a francia újságíró. Az ezredvégi receptek - immár gazdaságelméleti vagy politikai stratégiai „akcentussal” - Servan-Schreiber egykori üzeneteit ismétlik. ${ }^{36}$

Amerikai oldalról nézve a megvalósult „,föderális álom” - bármilyen nehezen született is meg, és bármilyen késôn, lassan és ellentmondásosan ment is végbe az Unió bővítése, és bármilyen nehézkes is az eurobürokrácia, mégiscsak akkora belső piacot teremtett, és olyan erejû́ innovációs energiatartalékot szabadított fel, ami az egykori „kihívásra” adott sikeres válasznak tekinthetô. ${ }^{37}$ Jeremy Rifkin hosszan sorolja azokat a területeket, ahol egyenesen az öreg kontinens került komoly helyzeti elónybe. ${ }^{38}$ Ezzel a diskurzus szốttese bonyolultabbá, kifinomultabbá válik: a tudás, az oktatás és a kultúra számos dimenziójában - a konzervált lemaradás kategóriáit ${ }^{39}$ „felülírva” - Európa néz vissza a mögötte tülekedókre...

Servan-Schreiber akkor, amikor európai-amerikai kontextusban tálalta a problémát, jól látta, hogy annak igazi mélyszerkezete túlmutat a dichotómián. A szereplók minden szempontból egymásra vannak utalva, sikereik a másikat is hajtják előre, a kudarcok az egész - mondjuk ki - világrendszernek ártanak. A diadalmas Egyesült Államoknak minden eredmény ellenére korlátozottak az eróforrásai, és a felek rá vannak utalva a kooperációra - nem (csupán) az utolérésre, a versenyre érdemes figyelni, hanem valamennyi szereplőnek a saját eredetiségét erôsítve kell egyre kívánatosabb együttmúködő partnerré válnia. S mindezt teljesen új „erôtérben”, egészen más „arcú” kapitalizmusban kell megvalósítani, melyben a termelés, az elosztás, a fogyasztás, valamint az érdek- és hatalmi viszonyok szinte minden eleme is a tudás új világának képére alakul át. ${ }^{40}$

Servan-Schreiber meggyôzoódése, hogy ez nemcsak a döntéshozók játszmája, hanem a kihívás az egyének számára is értelmezhetố. Ezért érez rá valóban az elsốk között az „életfogytig tartó tanulás” eszméjére. „A jövő kulcsa a permanens oktatás” mondja az Amerikai kihívásban (244). Az ismeretek megszerzését az egész emberéletre kell elosztani. ${ }^{41} \mathrm{Az}$ átképzés nagyobb alkalmazkodóképességet jelenthet, és ennek olyan társadalmi ígéretei vannak, hogy Európa élére állhatna az egész folyamatnak.

\footnotetext{
${ }^{36}$ Fagerberg, J. - Guerricri, P. - Verspagen, B. (eds.) (1999): The Economic Challenge for Europe: Adapting to Innovation-based Growth. Aldershot: Edward Elgar.

${ }^{37}$ Reid T. R. (2005): The United States of Europe: The New Superpower and the End of American Supremacy. Penguin (Non-Classics); Reprint edition.

${ }^{38}$ Rifkin, J. (2004): The European Dream. How Europe's Vision of the Future is Quietly Eclipsing the American Dream. New York: Tarcher.

${ }^{39}$ A legnagyobb kudarcról, a „lisszaboni fiaskóról” lásd Archibugi, Danicle - Coco, Alberto (2004): Is Europe Becoming the Most Dynamic Knowledge Economy in the World? Center for European Studies Working Paper; 2004. december, No. 119. http://www.ces.fas.harvard.edu/publications/docs/pdfs/ArchibugiTech.pdf

${ }^{40}$ Egy friss ,hommage à Servan-Schreiber”: Burton-Jones, Alan (2005): Knowledge Capitalism: Business, Work, and Learning in the New Economy. Oxford: Oxford University Press.

${ }^{41}$ Servan-Schreiber a legendás munkásvezetônél, Jaures-nál leli fel a gondolat ősforrását: „Attól a naptól fogva, amikor az emberi tevékenységek különféle formái közt szabad lesz az átmenet, amikor a foglalkozások közt kötetlen és folyamatos kicserélődés következik be, az emberek változó vagy kialakulatlan képességeit nem béklyózza meg többé az induláskor egyszer s mindenkorra változó hivatásuk: mindenfajta tevékenység állandó mozgásban lesz, s a még késốn jelentkezố hajlamok is utat törhetnek maguknak a váratlan felvirágzásra."
} 
A posztindusztriális társadalom „az állandó továbbképzés folyamatosan regenerálódó társadalma" (208).

Az információs társadalom eszméjének amerikai és japán panteonját benépesítô gondolkodókat, politikusokat és más közéleti szereplóket többé-kevésbé jól ismerjük. Ha az európai panteon lakóinak felsorolásába fogunk, kis habozás után kezdjük ServanSchreiberrel, és hökkenjünk meg, hogy Alain Touraine-en kívüi ${ }^{42}$ mennyire nehéz mellé társakat találni, egészen a nyolcvanas évek közepéig.

Befejezésül: e megkésett szakirodalmi „feltárás” és laudáció arra is figyelmeztet, hogy a kortárs diskurzusoktól időnként „ellépegetve” mennyire aktuális és termékeny lehet a visszatérés a korai percepciókhoz. ${ }^{43}$

${ }^{42}$ A mai napig Touraine-t tartják a posztindusztrális társadalom clsố curópai teoretikusának, pedig erról szóló könyve jóval Servan-Schreiberé után jelent meg ('Tourainc, Alain [1969]: La société post-industrielle. Naissance d'une société. Denoël-Gonthier). Az is igaz, hogy Tourainc a munkaszociológia felól indulva már az ötvenes évek közepén nemzetközi figyelmet kiváltó clemzćssel debütált (L'evolution du Travail Ouvrier aux Usines Renault. Paris: Centre National de la Recherche Scientifique, 1955, 202), azonnali, pozitív visszhangot váltva ki Amerikában (lásd Theodorc Caplow könyvismertetốjét: American Sociological Review, Vol. 20, No. 6, dec., 1955), 766-767. Külön érdekesség, hogy a könyv végsố formába öntése elốtt Touraine Rockefeller-ösztöndíjjal a Harvardon, a Columbián és a chicagói egyetemen folytatott tanulmányokat. Mellesleg az információs társadalom historiográfiájának francia fejezete ugyancsak megérne egy alapos áttekintést, ServanSchreiber és Touraine mellett olyan szcrzók újraolvasásával, mint Michel Crozier, Serge Mallet vagy Georges Gurvitch - és mindenekelőtt Jcan Gottmann nagyon is idôszcrú újrafelfedezésével az információs társadalom legelső klasszikusaként.

${ }^{43}$ Technológiai kontextusban az clốrejclzésck, a jövôképck utólagos mérlegre tétele mindig izgalmas szellemi kaland. (Egy ilyenre korábban magam is vállalkoztam „A jövô múltja - információtechnika és társadalom" címmel, Új Alaplap, 1998/1, 5-7.) A korabeli irodalom feltárása azonban ennél jóval többct credményezhet: azoknak a logikai struktúráknak, értelmezési kereteknek, jelentéseknek és fogalmaknak a rekonstrukcióját, amelyek az akkori gondolkodást és a vitapozíciókat meghatározták - s amclyck révén mai ismeretcink bázisán gazdagabban tudjuk elemezni a múltat, és számos csapdától megóvhatjuk magunkat, ha kedvünk támad kisablakot nyitni a jövốre. 